УДК 636.03

МЕТОДОЛОГИЯ УПРАВЛЕНИЯ ФОРМИРОВАНИЕМ

ФУНКЦИОНАЛЬНО-ТЕХНОЛОГИЧЕСКИХ СВОЙСТВ ЖИВОТНОВОДЧЕСКОГО СЫРЬЯ ЗА СЧЕТ ОПТИМИЗАЦИИ

СЕЛЕКЦИОННЫХ И ПАРАТИПИЧЕСКИХ ФАКТОРОВ

\title{
METHODOLOGY FOR MANAGEMENT OF FORMATION \\ FUNCTIONAL-TECHNOLOGICAL PROPERTIESOF RAW MATERIALS OF ANIMAL ORIGIN IN THE ACCOUNT OF OPTIMIZATION OF SELECTION AND PARAPYPIC FACTORS
}

Сложенкина М.И., доктор биологических наук, профессор Горлов И.Ф., доктор сельскохозяйственных наук, профессор, академик РАН

Ранделин А.В., доктор биологических наук, профессор

Мосолов А.А., доктор биологических наук,

Злобина Е.Ю., кандидат биологических наук

Княжеченко О.А., младший научный сотрудник

Slozhenkina M.I., doctor of biological sciences

Gorlov I.F., doctor of agricultural sciences, professor, academician of RAS

Randelin A.V., doctor of agricultural sciences, professor

Mosolov A.A., doctor of biogical sciences

Zlobina E.Yu., candidate of biological sciences

Knyazhechenko O.A., junior scientific researcher

Поволжский научно-исследовательский институт производства

и переработки мясомолочной продукции, Волгоград

Volga region research institute of manufacture and processing

of meat-and-milk production, Volgograd

В статье систематизированы результаты выполненной работы, в ходе которой сотрудниками института были сформулированы новые высокоэффективные подходы к разработке инновационных методов воздействия на организм сельскохозяйственных животных с целью прижизненного формирования качественных характеристик социально значимых пищевых продуктов повышенной биологической ценности. 
The article systematizes the results of the work performed, during which the staff of the Institute formulated new highly effective approaches to the development of innovative methods of influencing the organism of agricultural animals with the purpose of intimately forming qualitative characteristics of socially significant food products of increased biological value.

Ключевые слова: селекционные методы, кормление, прижизненное формирование, паратипические факторы, управление качеством.

Keywords: selection methods, feeding, intravital formation, paratypic factors, quality management.

Современное сельское хозяйство развивается в направлении усиления производства наукоемкой продукции. Если говорить о производстве животноводческой продукции, то это создание и использование новых селекционных достижений, инновационных подходов к повышению продуктивного действия кормов, внедрение ресурсосберегающих технологий и оптимизация организации труда, соблюдение экологических и ветеринарно-санитарных требований и т.д.

ГНУ НИИММП имеет свой почерк по проведению исследований производства животноводческой продукции по всей биотехнологической цепи, то есть от поля до потребителя. Работа проводится по гостематике, а также по грантам РНФ, Президента РФ, хоздоговорным НИР. Было проанализировано современное состояние животноводства ЮФО. Дана оценка актуальности исследований, направленных на разработку высокоэффективных подходов к повышению эффективности производства продукции животноводства с учетом региональных особенностей. В результате изучения экспериментальных данных обоснована научно-практическая значимость разведения крупного рогатого скота мясных пород, являющихся на сегодняшний день ведущими в России, имеющими большое племенное значение в мясном скотоводстве и характеризующиеся уникальными качествами.

Изучены хозяйственно-биологические особенности сельскохозяйственных животных различных пород и внутрипородных типов: помесные бычки, полученные в результате скрещивания молочных коров чернопестрой породы с герефордскими быками (I); помесные бычки, полученные в результате скрещивания молочных коров бестужевской породы с герефордскими быками (II); чистопородный молодняк симментальской породы (III); чистопородный молодняк герефордской породы (IV); чистопородный молод- 
няк абердин-ангусской породы $(\mathrm{V})$; чистопородный молодняк лимузинской породы (VI).

При изучении влияния на организм животных транспортного стресса установлено, что наибольшие потери живой массы установлены у бычков лимузинской породы. Результаты физиологических исследований показали, что более стрессоустойчивыми при автомобильной транспортировке и предубойной подготовке являются чистопородные бычки герефордской и симментальской пород. Данный факт необходимо учитывать при прогнозировании стрессовых ситуаций, влияющих на процесс производства говядины для предприятий, занимающихся выращиванием и откормом молодняка крупного рогатого скота [7].

Изучены интенсивность роста и развития, особенности формирования мясной продуктивности чистопородных и помесных бычков, полученных в результате однократного и двукратного вводного скрещивания герефордских быков с коровами казахской белоголовой породы. Установлено, что помесные бычки превосходят чистопородных сверстников I группы по живой массе, среднесуточному и абсолютному приросту. Высокой живой массой характеризовались бычки с генотипом 1/2 (II группа) и 3/4 (III группа) по герефордской породе. Наиболее высокая мясная продуктивность бычков II и III групп установлена и по результатам их контрольного убоя. Выход туш у молодняка II группы составил 57,18\%, что выше, чем у сверстников I и III групп, на 1,38 и 1,47\%. Убойный выход по данной группе был выше соответственно на 1,46 и 1,59\%. По массе мякоти в тушах молодняк из II группы превосходил сверстников на 8,49 и 6,51\%, выходу мякоти - на 1,08 и 0,27\%. Индекс мясности туш бычков II группы был выше, чем сверстников, на 6,06 и 1,47\%, масса наиболее ценного тазобедренного отруба была больше на 8,06 и 2,68\%. Уровень рентабельности производства говядины от бычков II группы был выше, чем у молодняка I и III групп, на 11,87 и 9,37\%.

Проведена иммуногенетическая аттестация изучаемого поголовья с целью дальнейшего выявления взаимосвязи наследования аллелей групп крови с формированием хозяйственно-биологических особенностей. Генотипы исследованных особей по ISSR-маркерной системе соответствуют генофонду русской комолой и абердин-ангусской пород с высоким уровнем достоверности за исключением одной помесной особи в исследованном поголовье русской комолой и двух бычков абердин-ангусской (среди коров помесных животных не выявлено). Популяция исследованного поголовья герефордской породы неоднородна и не консолидирована: 14 особей имеют генотипы, отличающиеся от генофонда заявленной породы, и одна особь представляет собой помесное животное. Среди животных с отличающимися от 
генофонда герефордской породы генотипами 7 быков (50\%), 7 коров (22,6\%) и 1 телка (20\%). Количество особей с чужеродными генотипами в целом составляет 30\% (15 особей). В формировании помесной популяции между КРС казахской белоголовой и герефордской пород участвовали обе породы, и сформированная популяция консолидирована и однородна. На однородность популяции указывает высокий уровень сходства генотипов исследованных телок с генофондом популяции и высокая достоверность полученных данных [2].

Проведено геномное сканирование племенного поголовья калмыцкой породы с использованием чипа illumina SNP IDBv3 BeadChip с целью идентификации SNP-профилей и оценки племенной ценности животных, разработаны рекомендации по применению ДНК-маркеров и использованию результатов при создании селекционных программ совершенствования существующих и выведения новых пород и внутрипородных типов, разработаны рекомендации по ведению селекционной работы в направлении создания племенных стад с высоким генетическим потенциалом, формированию их оптимальной генеалогической структуры на основе современных молекулярногенетических методов исследования ДНК, продолжены исследования адаптационных и хозяйственно-биологических особенностей голштинского скота разных эколого-генетических типов: установлена адаптационная способность коров, завезенных из США, Дании, Германии и Австралии; изучены закономерности роста и развития коров-первотелок голштинской породы разных селекций; проведена оценка состояния естественной резистентности и иммунного статуса животных; определены их продуктивные способности и репродуктивные качества; проанализированы биологические (генетикостатистические) параметры в зависимости от генотипа; проведена ДНКдиагностика гена каппа-казеина коров голштинской породы разных селекций (во всех случаях обнаружены генотипы АА); определены качественные показатели молока подопытных телок с экономической оценкой результатов акклиматизации.

Изучены внутрипородные типы (генофонд) отдельной популяции калмыцкой породы крупного рогатого скота: интенсивность роста и уровень мясной продуктивности бычков линии Зиммера 7333, Стройного 2520 и Лелешко 15 при интенсивном откорме. Уровень рентабельности производства мяса от бычков линии Зиммера 7333 был выше, чем у сверстников, на 11,5 и 6,5\%. При молекулярно-генетической оценке уровня инбридинга также выделены три основные по происхождению животных кластера, что позволяет оценить точность распределения животных по линиям и подобрать будущую селекционную стратегию. Селекционная работа и разведение животных 
должны быть построены с учетом особенностей происхождения животных. Животные кластера № 3 и их предки должны скрещиваться с учетом принадлежности к подгруппам кластера, с минимальным скрещиванием животных из одной подгруппы. При необходимости ведения селекционной работы по линиям возможно также учитывать пространственное расположение индивидуумов по линиям. Анализ по признаку «живая масса», позволил выявить три снипа с достоверностью выше пороговой, отвечающие за такие клеточные процессы, как рост, генная регуляция, передача сигнала и генная регуляция, катализ и синтез диацилглицерина из моноглицеридов и жирных кислот, что играет ключевую роль в поглощении жирных кислот организмом. Два из трех снипов, выявленных в анализе и прошедших порог достоверности по признаку «среднесуточный прирост», совпадают со снипами, выявленными при ассоциативном анализе по признаку «живая масса». Схожесть результатов ассоциативного анализа отражает вероятную связь SNP с набором массы у крупного рогатого скота калмыцкой породы, так как оба признака статистически тесно связаны, а выявленные снипы расположены рядом с генами, отвечающими за процессы формирования и развития клеток. По признаку «высота в крестце» выявлены снипы, отвечающие за раннее развитие эмбриона, каркас и качество мяса. По признаку «ширина в маклоках» выявлены снипы, отвечающие за рост и развитие клеток, а также ранний эмбриогенез. Наличие снипов, ассоциированных с признаком, может говорить о наличии гена кандидата на обширном участке и высоком сцеплении SNP по неравновесию.

Дано научное обоснование эффективности кратности использования герефордских быков при скрещивании с маточным поголовьем казахской белоголовой породы (заволжский тип) и ее влиянию на продуктивность и качественные показатели мяса, полученного от потомства: изучены хозяйственно-биологические особенности молодых животных, полученных при одно- и двукратном скрещивании герефордских быков с маточным поголовьем казахской белоголовой породы (заволжский тип); дана экономическая оценка производству говядины, полученной от молодняка казахского белоголового скота (заволжский тип) отдельных генотипов по герефордской породе.

С учетом требований к созданию пастбищ с высокой урожайностью, продуктивным долголетием, быстрым достижением пастбищной спелости, устойчивости к выпасу и вытаптыванию, а также высоким содержанием ненасыщенных жирных кислот были отобраны 3 вида трав: райграс (плевел многолетний) + многолетнее сорго + волоснец. Изучение изменчивости содержания жирных кислот в кормовых травах показало, что сезонные и экологические факторы играют значительную роль в фенотипической вариации 
содержания жирных кислот, что, в свою очередь, потребует корректировки жирнокислотного состава кормов в процессе выращивания. Эксперимент по изучению скорости поглощения, переваривания и выделения хлоропластов микрофлорой рубца методом in vitro оказался невозможен из-за проблем жизнеспособности и концентрации простейших. Аналогичный по цели эксперимент методом in vivo показал, что поглощение простейшими рубца хлоропластов растений происходит быстро, и внутриклеточный уровень хлоропластов поддерживается в течение, по крайней мере, 6 часов. Оценка степени сохранности ПНЖК до попадания в двенадцатиперстную кишку показала, что данный процесс связан с целым комплексов факторов и взаимодействий, происходящих между компонентами кормовых трав и микрофлорой рубца животных. Установлено, что скармливание трав с различными уровнями содержания полифенолоксидазы имеет ограниченный потенциал для улучшения жирнокислотного профиля липидов в мясе жвачных животных ввиду отсутствия достоверного уровня снижения процессов биогидрирования. При этом лучшие результаты показало скармливание животным силоса травы ежи обыкновенной с высоким уровнем полифенолоксидазы. Существенное торможение биогидрогенации обеспечивает включение в рацион кормовых трав, содержащих сапонины (1\% деодоразы) и танины (лядвенец топяной). Однако эффективность присутствия танинов, вероятно, связана с тем, что концентрированные танины, присутствующие в L. Pedunculatus (лядвенец топяной), были очень токсичны для микрофлоры рубца.

На основе математического моделирования спрогнозированы качественные показатели говядины, полученной от бычков казахской белоголовой и калмыцкой пород. Изучены рост, развитие и убойные качества бычков разного типа телосложения, определены направление и величина коррелятивных связей между изучаемыми признаками и выявлены основные факторные показатели (маркеры) для прогноза мясной продуктивности бычков; разработаны модели для прогноза мясной продуктивности бычков и качественных показателей говядины. Установлены положительные коррелятивные связи между живой массой подопытных бычков и промерами экстерьерных статей. Разработанная модель дает возможность осуществлять прогнозирование основных показателей убоя подопытных бычков по живой массе, высоте в холке, косой длине зада в раннем возрасте.

Учеными НИИ проведена сравнительная оценка хозяйственнополезных признаков коров голштинской породы разных селекций. Выявлено превосходство коров из Германии и Австралии над сверстницами датской и американской селекций. Максимальный удой был получен от американских и немецких коров (25220 и 24861 кг), в их молоке было выше содержание 
жира. Максимальное содержание белка было в молоке австралийских и американских коров $(3,47$ и 3,38\%). Выход телят от американских, датских, немецких, австралийских коров составил 87, 82, 84 и 83\%. Более высоким содержанием эритроцитов, общего белка, более высокими показателями фагоцитоза характеризовались животные из Дании и Австралии, что свидетельствует об особенностях гомеостаза животных этих генетических селекций в условиях адаптации.

Первотелки американской селекции в первую и вторую лактации показывают отрицательную взаимосвязь признаков, что указывает на более длительный период акклиматизации по сравнению с другими генотипами. Наиболее устойчивая и высокая корреляционная зависимость между изученными признаками отмечена у голштинов из Дании. При этом в результате математического моделирования процессов акклиматизации установлено, что с увеличением срока хозяйственного использования голштинов разных селекций предпочтение по вышеуказанным показателям следует отдать коровам датской селекции.

Изучен полиморфизм генов GDF9, CASP, MC4R у овец волгоградской и сальской пород, а также породы советский меринос, разработаны рекомендации по совершенствованию селекционной работы племенных хозяйств на основе выявления взаимосвязи генетических маркеров с формированием продуктивных качеств мелкого рогатого скота. У овец установлены высокие частоты аллеля G и генотипа GG по точке G1 и аллеля А и генотипа АA по точке G4 гена GDF9. Все особи, гетерозиготные по точке G1, были также гетерозиготными по точке G4. Гомозиготные генотипы AA (G1) и GG (G4) в исследуемой популяции отсутствовали. Желательные аллельные варианты GDF9/G1-A и GDF9/G4-G, связанные с повышением плодовитости овец, в изучаемой популяции имеют низкую частоту и установлены только в гетерозиготном состоянии. Для повышения частоты желательных аллелей в популяции рекомендуется проводить ДНК-тестирование гена GDF9 с целью отбора ремонтного молодняка с желательными генотипами. В гене GDF9 были определены восемь различных точечных мутаций (G1-G8). Три мутации из восьми не приводят к изменению аминокислотной последовательности (G2, $\mathrm{G} 3$ и $\mathrm{G} 5)[3,6]$.

Установлено, что пять оставшихся нуклеотидных замен (G1, G4, G6, G7 и G8) приводят к аминокислотным заменам. Установлено влияние полиморфизма гена GDF9 на массу ягнят волгоградской породы при рождении. У маток генотипа AG вес ягненка при рождении в одинцовых пометах (первый окот) был выше на 0,14 кг (4,02\%) по сравнению с матками генотипа GG. Bo втором окоте вес ягнят из двоен, полученных от маток генотипа $\mathrm{AG}$, был 
выше на 0,18 кг (7,11\%). Достоверных различий по плодовитости между матками генотипов AG и GG гена GDF9 в исследуемой группе не установлено. Анализ продуктивных качеств показал, что полиморфизм гена CAST связан с ростовыми показателями овец в 12 мес. В 12 мес. овцы генотипа ММ в среднем весили 50,4 кг и превышали аналогичный показатель овец генотипа NM на 1,12 кг (2,28\%). Достоверного влияния полиморфизма гена CAST на вес в 8 мес. и на шерстную продуктивность овец не установлено. Контроль полиморфизма гена MC4R может использоваться в селекции, направленной как на снижение жира, так и на увеличение. Производители могут выбрать аллель $\mathrm{A}$, связанный с быстрым ростом, или аллель $\mathrm{G}$, связанный с постным мясом и эффективным приростом. У овец волгоградской породы установлено наличие трех генотипов: AA, AG и GG с частотой встречаемости 12,0; 59,4 и $28,6 \%$ соответственно. В целом у волгоградской породы овец наибольшую частоту имел аллель $\mathrm{G}$ и гетерозиготный генотип AG. Наличие изменчивости по данным локусам дает основание для контроля мясной продуктивности у овец волгоградской популяции овец, поэтому в генофондных и племенных хозяйствах следует проводить мониторинг полиморфизма и селекцию по гену меланокортиновый рецептор-4 (MC4R).

Частота генотипов $\mathrm{AA}, \mathrm{AB}$ и $\mathrm{BB}$ гена роста $\mathrm{GH}$ установлена в соотношении 57, 36 и 7\% соответственно. В целом у сальской породы овец наибольшую частоту имел аллель А и гомозиготный генотип АА. Наличие гетерозиготного генотипа $\mathrm{AB}$ у баранчиков сальской породы положительно связано с темпами роста молодняка. По живой массе при отъеме и в 9 мес. баранчики с генотипом АВ превосходили баранчиков с генотипом АA на 0,92 и 10,67 кг соответственно. Гетерозиготный генотип также связан с лучшими среднесуточными приростами в период с 2 до 9 месяцев. Среднесуточный прирост у баранчиков с гетерозиготным генотипом АВ был больше на 47,3 г по сравнению со сверстниками с генотипом АА. Наибольшие темпы роста животные данного генотипа имели в послеотъёмный период.

Наилучшую мясную продуктивность имели баранчики генотипа $\mathrm{AB} / \mathrm{GH}$, которые достоверно превосходили аналогов генотипа AA/GH практически по всем анализируемым признакам. От баранчиков генотипа AB/GH была получена большая масса туши и масса мякоти: на 4,97 и 1,83 кг соответственно. Убойная масса и убойный выход у баранчиков генотипа $\mathrm{AB} / \mathrm{GH}$ также превышали данные показатели баранчиков генотипа AA/GH на 4,83 кг и $2,04 \%$ соответственно.

Дополнительно была проведена оценка массы внутренних органов. В результате было определено, что наличие генотипа $\mathrm{AB}$ у животных волгоградской породы связано с большей массой сердца и почек на 69,12 и 75,44 г 
соответственно. Достоверных различий по другим признакам (масса селезенки, легких, печени) установлено не было.

Таким образом, полученные результаты показали перспективность изученных генов в качестве маркеров откормочной и мясной продуктивности овец и позволили разработать селекционные программы по совершенствованию сальской породы овец с учетом полиморфизма гена GH. Отсутствие полиморфизма по генам BMPR1B и BMP15 не позволяет рассматривать их в качестве генетических маркеров для овец сальской породы. Определены аллельные варианты микросателитных локусов OarCP49, CSRD247, FCB20, MAF65, CSAP36, McM14, D5S2 и HSC и получены данные, характеризующие генетическую структуру овец волгоградской породы. Дефицит гетерозигот в популяции отмечен по локусам MAF65, CSAP36 и HSC, что можно рассматривать как тенденцию к повышению гомозиготности в стаде за счет использования родственного спаривания. Однако недостаток гетерозигот в популяции можно интерпретировать и как один из критериев подразделенности, характеризующий уровень биологической организации популяции как целого. Получены данные о нуклеотидной последовательности D-петли мтДНК волгоградской породы овец и проведен анализ ее полиморфизма в сравнительном аспекте с мериносовыми и тонкорунными породами отечественной (казахская, кулундинская) и зарубежной селекции (алтайская мериноландшаф, австралийский меринос и австралийский ромни-марш, тексель), рассчитано расстояние между названными породами.

Генофонд волгоградской породы овец представлен вариантами гаплотипов, входящих в широко распространенную гаплогруппу В, что характерно для европейских пород овец. Также в гаплогруппу В входят породы: кулундинская, казахская, тексель, мериноландшаф. Мериносы австралийской селекции относятся к гаплогруппе А, а алтайская порода определена к гаплогруппе $\mathrm{C}$, которая характерна для китайских пород овец.

Моделирование генетической структуры путем расчета аллельных комбинаций позволяет прогнозировать племенную ценность будущего потомства, значительно сокращая селекционный процесс, формировать продуктивные качества животных, функционально-технологические свойства животноводческого сырья, повышая рентабельность производства. Свиньи породы крупная белая (КБ) генотипа AG/MC4R отличаются лучшей скороспелостью на 5,35 дн. (3,16\%), среднесуточным приростом на 82,3 г $(9,9 \%)$, меньшими затратами корма на 0,13 корм. ед. (на 4,16\%) по сравнению с генотипом АА. Свиньи КБ генотипа QQ/IGF2 отличаются от аналогов qqгенотипа лучшей скороспелостью на 6,1 день (на 3,7\%), среднесуточным приростом на 59,7 г (7,7\%), толщиной шпика на 1,8 мм $(7,8 \%)$ и затратами 
корма на 0,1 корм. ед. (3,2\%). Свиноматки КБ генотипа QQ по сравнению с матками генотипа qq имеют лучшую молочность на 10,1 кг (15\%) и массу гнезда при отъеме на 11,4 (12,3\%). По гену POU1F1 для свиней КБ «желательным» является генотип СС: который обеспечивает лучшую скороспелость на 8,86 дн. (5,2\%), среднесуточные приросты на 150,7 г (17,7\%), меньше затраты корма на 0,24 корм. ед. (8,2\%).

По воспроизводительным качествам свиноматки КБ генотипа СС отличаются лучшей крупноплодностью на 0,16 кг (11,3\%), молочностью на 12,2 кг (15,9\%), массой гнезда и 1 поросенка при отъеме на 16,7 кг (18,4\%) и 1,3 кг $(15,2 \%)$ соответственно. Установлено, что при учете влияния генотипов одновременно по двум генам POU1F1 и IGF2 достоверность влияния генетической составляющей значительно повышается. «Желательным» является генотип CDQQ. Свиньи этого генотипа отличаются от аналогов других генотипов лучшей скороспелостью на 6,2-10,8 дн. (3,7-6,2\%), среднесуточным приростом на 32,0-82,3 г (4-10,2\%), меньшей толщиной шпика на 2,2-2,85 мм (9,3$11,75 \%)$ и затратами корма на $0,05-0,13$ корм. ед. (1,63-4,13\%). При совместном учете влияния генов POU1F1 и MC4R в качестве «желательных» по откормочным качествам для свиней КБ являются генотипы CCAA и CDAG. Свиньи КБ с генотипом CDAG по сравнению с аналогами генотипов CDAA, DDAG и DDAA отличаются интенсивными среднесуточными приростами на 77,5 г $(9,9 \%), 96,0$ г (11,1\%) и 120,9 г $(16,4 \%)$ и затратами корма на 0,09 корм. ед. (3\%), 0,12 корм. ед. (4,04\%), 0,15 корм. ед. (4,14\%) соответственно.

В результате экспериментальных исследований дано научное обоснование и реализованы в производственных условиях новые методы повышения продуктивных и воспроизводительных качеств свиней отечественных пород в условиях промышленной технологии за счет использования специализированных мясных пород иностранной селекции: изучена продуктивность свиней пород крупная белая, дюрок, ландрас и йоркшир, выращиваемых на крупном промышленном комплексе в регионе Нижнего Поволжья; определено влияние породной принадлежности на воспроизводительные особенности свиноматок специализированных мясных пород; установлено влияние двухи трехпородных помесей на формирование мясной продуктивности при откорме свиней до разных весовых кондиций; изучены продуктивные показатели свиней при откорме чистопородных и помесных животных; проанализированы воспроизводительные функции свиней разных пород; дана экономическая оценка производству конкурентоспособной свинины от животных различных пород и их помесей [1].

Разработана технология получения экструдированного корма высокого качества за счет использования при его приготовлении отходов маслично- 
го производства (нетрадиционных культур) и зерна нута новых селекций. Предложенный способ откорма молодняка крупного рогатого скота мясного направления позволяет в значительной степени увеличить производство высококачественной говядины. Так, в мясе, полученном от бычков опытной группы, содержание белка было выше в сравнении с контрольной группой на $1,30 \%(\mathrm{P}<0,01)$, сухого вещества - на 1,90\% $(\mathrm{P}<0,01)$, жира - на 0,70\% $(\mathrm{P}<0,05)$, золы - на 0,06\%, а белковый качественный показатель был выше на $0,31 \%$.

Проведен эксперимент по определению развития мускулатуры и мраморности у казахской белоголовой породы путем подкормки жмыхом и фузом из семян тыквы. Для эксперимента были сформированы 3 группы бычков в возрасте 10 месяцев по 10 голов в каждой. Эксперимент длился 8 месяцев. Молодняк контрольной группы получал основной рацион, I группы - рацион с добавлением 180 г жмыха, II - 180 г фуза из семян тыквы. Пищевая ценность корма для испытуемых бычков была рассчитана на получение среднесуточного прироста живой массы на уровне 1100-1200 г. Основной корм для испытуемых телят в зависимости от возраста составлял от 2,0 до 3,5 кг сена зерновых и зернобобовых, 9,0-15,0 кг сенажа, 3,1-4,0 кг комбикорма и 0,4 кг свеклы мелассы. Для развития мраморной технологии была проведена оценка экстерьера и динамики суточного прироста животных. Проводилась оценка сортового состава туши, осаждения, локализации и качества жировой ткани. Анализ данных показал, что введение в рацион крупного рогатого скота жмыха и фуза из семян тыквы позволяет увеличить прирост на 29,8 кг и получить говядину категории А3 по стандарту B.M.S. (Стандарт Мраморности говядины). Использование жмыха и фуза из семян тыквы позволяет повысить развитие мускулатуры у животных казахской белоголовой породы и формирование мраморности в говядине.

Впервые в условиях Южного Федерального округа изучено влияние новых кормовых добавок на основе микроэлементов в органической форме, органических кислот на потребление, переваримость, усвояемость, конверсию питательных веществ рационов в организме животных, интенсивность роста и уровень их продуктивности. Изучена эффективность комплексного использования в рационах бычков, выращиваемых на мясо, кормовых добавок «Йоддар-Zn» и «Глималаск-Вет». Значимость исследований заключатся в расширении знаний о воздействии кормовых добавок, разработанных на основе микроэлементов в органической форме и органических кислот, на рост, развитие, убойные качества, морфологический состав туш и качество мяса молодняка крупного рогатого скота [4]. 
Использование в кормлении бычков кормовой добавки «Йоддар-Zn» раздельно и в комплексе с «Глималаск-Вет» позволяет повысить конверсию питательных веществ кормов в мясную продукцию, интенсивность роста и развития молодняка, а также дополнительно производить от 18,32 до 33,84 кг говядины и повысить уровень рентабельности на 4,32 и 7,38\%.

Установлено, что использование в рационах молодняка свиней на откорме новых кормовых добавок «КореМикс» и «СалтМаг», разработанных при участии научного коллектива института, способствует улучшению переваримости и использования основных питательных веществ рационов, повышению мясной продуктивности и качества свинины, уровень рентабельности повысился на 4,4 и 3,9\%. Антибактериальный препарат Лексофлон OR показал высокую профилактическую и терапевтическую эффективность (98\%) при выращивании поросят, способствовал активизации у них обменных процессов, повышению естественной резистентности и увеличению прироста живой массы к концу выращивания.

Разработаны новые ресурсосберегающие биотехнологические приемы повышения продуктивного действия сельскохозяйственных кормов. Опыт проводился на цыплятах-бройлерах. Введение в рацион цыплят-бройлеров Lаспарагинатов микроэлементов (ОМЭК) способствует значительному повышению переваримости основных питательных веществ кормов. Выявлено влияние микроэлементного комплекса на содержание микроэлементов в костях, грудных мышцах и помёте. Использование в кормлении цыплятбройлеров L-аспарагинатов марганца, железа, меди и цинка (в связи с их высокой биодоступностью) позволяет снизить содержание микроэлементов в премиксе от принятых гарантированных норм в расчете на активное вещество и обеспечивает необходимое депонирование микроэлементов в костяке бройлеров. Целесообразность использования в кормлении цыплят-бройлеров органических минералов обосновывается повышением степени усвоения органических форм цинка, меди, железа и марганца, возможностью более точно нормировать эти микроэлементы и поддерживать здоровье животных, их продуктивные и воспроизводительные качества. Кроме того, органические минералы позволяют существенно снизить загрязнение окружающей среды благодаря снижению их концентрации в помете [5].

Разработаны и научно обоснованы инновационные технологии получения и применения белоксодержащих продуктов из нута различных селекций при производстве пищевых изделий и кормовых средств с учетом генетических особенностей и функционально-технологических свойств белков.

Поставлен научно-хозяйственный эксперимент на молодняке свиней с целью сравнительного изучения влияния рациона с использованием экстру- 
дата нута совместно с кормовой добавкой «КореМикс», содержащей в своем составе сорбирующие кремнийсодержащие минералы и пробиотические микроорганизмы, на поедаемость кормов, переваримость и использование питательных веществ, продуктивность и качество мяса молодняка свиней на откорме, уровень рентабельности повысился на 4,4\%.

Научно обоснована и реализована в производственных условиях возможность замены в рационах мясной птицы части соевого шрота и рыбной муки на зерно нута, определены оптимальные дозы ввода нута, изучена биологическая ценность комбикормов нового растительного типа с различным уровнем в рационе зерна нута для цыплят бройлеров, племенного молодняка и взрослого поголовья кур мясного направления. Установлено влияние на их ростовые и откормочные качества; определено влияние изучаемых рационов на развитие органов пищеварительного тракта, переваримость питательных веществ рационов, баланс и использование азота, кальция и фосфора в организме испытуемой птицы; рассчитана экономическая эффективность и доказана практическая значимость использования в составе растительных рационов различного процента зерна нута для цыплят-бройлеров, ремонтного молодняка и маточного поголовья.

Таким образом, в результате выполнения работы, сотрудниками института сформулированы новые высокоэффективные подходы к разработке инновационных методов воздействия на организм сельскохозяйственных животных с целью прижизненного формирования качественных характеристик социально значимых пищевых продуктов повышенной биологической ценности за счет выявления особенностей генома на основе использования генетических маркеров, отвечающих за продуктивные, количественные и качественные показатели животноводческого сырья, создания принципиально новых видов подкормок, премиксов, биологически активных добавок и использования инновационных биотехнологических приемов совершенствования технологии кормления с целью повышения продуктивного действия кормов и создания систем наиболее полной реализации генетического потенциала продуктивности животных.

\section{Библиографический список}

1. Горлов, И.Ф. Воспроизводительные и адаптационные качества свиней канадской селекции при промышленном разведении в Нижнем Поволжье / И.Ф. Горлов, М.И. Сложенкина, Д.В. Николаев, Ю.Н. Фёдоров // Сельскохозяйственная биология. - 2017. - Т. 52. - № 4. - С. 803-811.

2. Сулимова, Г.Е. Характеристика генофондов российских мясных пород крупного рогатого скота с использованием межмикросателлитного ана- 
лиза ДНК (ISSR-анализ) / Г.Е. Сулимова [и др.] // Генетика. - 2016. - № 9. С. 1081-1088.

3. Gorlov, I.F. Association of the growth hormone gene polymorphism with growth traits in salsk sheep breed / I.F. Gorlov [et al.] // Small Ruminant Research. - 2017. - T. 150. - C. 11-14.

4. Gorlov, I.F. Effects of feed additives "Yoddar-Zn" and "Glimalask-Vet" on the productivity of beef cattle / I.F. Gorlov, A.T. Lebedev, V.Y. Galkov, A.V. Orlyanskiy, S.N. Shlykov // Research Journal of Pharmaceutical, Biological and Chemical Sciences. - 2016. - T. 7. - № 5. - C. 2518-2522.

5. Gorlov, I.F. Aspartate-complexed minerals in feeding broiler chickens / I.F. Gorlov, Z.B. Komarova, E.Y. Zlobina, E.V. Karpenko, D.N. Nozhnik // Research Journal of Pharmaceutical, Biological and Chemical Sciences. - 2016. T. 7. - № 5. - C. 2890-2898.

6. Gorlov, I.F. CAST/MSPI gene polymorphism and its impact on growth traits of soviet merino and salsk sheep breeds in the south European part of Russia / I.F. Gorlov [et al.] // Turkish Journal of Veterinary and Animal Sciences. - 2016. - T. 40. - № 4. - C. 399-405.

7. Levakhin, V.I. Change in physiological parameters of calves of various breeds under the transport and pre-slaughter stress / V.I. Levakhin [et al.] // Nusantara Bioscience. - 2017. - № 1. - C. 1-5. 